ago, are an order of magnitude less restrictive than the National Institutes of Health $(\mathrm{NIH})$ regulations. Tooze hoped that Italy and Japan, still finalising their regulations, would follow France.

Several representatives of large industrial concerns were optimistic regarding the potential benefits of recombinant DNA technology to health and industry. The first benefit is likely to be improved bacterial strains, some providing increased yields of enzymes of industrial importance. Further ahead should lie the production of highly specific vaccines. For example, S. Falkow from Washing- ton University, Seattle, spoke of the potential as a cholera vaccine of a product of the cloned gene for the heat-labile $E$. coli enterotoxin.

The most tangible of the muchvaunted benefits of recombinant DNA, however, lies in the production of hormones. As far as can be judged the running in that race is being made by smaller industries spawned by the technology and with very close links to universities. In particular there is Genentech, a firm whose founders include $\mathrm{H}$. Boyer of the University of California, San Francisco. His university group has recently succeeded in chemically synthesising the gene for the hormone somatostatin incorporating it into a bacterial plasmid and then showing that when the plasmid entered host $E$. coli, the bacteria synthesised the hormone. The same techniques are now being applied to the production of insulin, a remarkable goal that is on target to being accomplished before the end of the year. Boyer estimates that the cost of insulin produced in that fashion should be no more than for that now purified commercially from slaughterhouse pancreatic tissue. Furthermore the insulin from Boyer's technique should be purer and could be of human origin and sequence.

\title{
Friends of DNA fight back
}

\section{David Dickson describes an unpublicised campaign by university} administrators to halt community participation in DNAlegislation

FOUR American universities have employed a Washington attorney as a professional lobbyist-although initially unregistered-in an attempt to prevent the passage of legislation allowing state or local participation in establishing regulations covering research using recombinant DNA techniques.

Already three of the four universities - Harvard, Stanford and Princetonface the possibility of state legislation covering such research; and Harvard has been made subject to local ordinances passed last year by Cambridge City Council.

At the fourth, Washington University in St Louis, little research involving recombinant DNA is being done, but an official said last week that they were concerned with the principle.

The issue of Federal preemptionFederal legislation that overrides state or local initiatives-lies at the heart of the current dispute. Public interest groups argue that local communities should be directly involved in drawing up regulations for research carried out in their midst, pointing to events at Cambridge to show how this can be done in what they claim to be a reasonable and moderate manner.

In contrast, many of the scientists argue the need for Federal preemption to provide uniform safety standards and prevent research workers moving to localities with less stringent regulations. Dr Philip Handler, president of the National Academy of Sciences told a Congressional Committee last week that the Federal preemption in the Bill now before the House of Representatives was "a particularly constructive feature".
Much of the opposition from the scientific community which led to last year's suspension of Congressional activity on DNA legislation was the result of a well-publicised campaign. At the same time, however, an unpublicised lobbying effort was conducted by university administrators concerned that DNA legislation could set a dangerous precedent for demands for community involvement in other areas of university activity.

Although the lobbying attempt has been done primarily through Harvard, more than 70 individuals at over 35 universities throughout the country have been involved through an informal network known as the 'Friends of DNA'. Only half of these are scientists; the rest are involved in university administration, in particular through offices of public affairs or similar liaison units.

The universities' concern at the implications of DNA legislation was first raised a year ago when Representative Paul G. Rogers, chairman of the Health and Environment Subcommittee of the House Committee on Interstate and Foreign Commerce, introduced an Administration-backed Bill which would have permitted state or local legislatures to impose conditions on DNA research more stringent than Federally-agreed guidelines determined by the National Institutes of Health.

Many scientists reacted strongly against this suggestion. On 26 April last year, a resolution signed by 13 members was passed by the National Academy of Sciences claiming that the proposed legislation would subject DNA research to "arbitrary regula- tions" at the local level which would "severely degrade" the capability of biomedical research.

Dr Harlyn Halvorson of Brandeis University, then president of the American Society for Microbiology, started a campaign among professional scientific societies through the InterSociety Council for Biology and Medicine whose objectives included "a single set of uniform national standards governing recombinant DNA activities". At the same time, the four private universities-Harvard, Stanford, Princeton and Washingtonagreed to contribute towards the expenses of a professional lobbyist, Ms Nan Nixon, who would argue for Federal-preemption in any DNA legislation.

She has conducted a vigorous lobbying campaign on the universities' behalf in collaboration with Mr Donald Moulton, until recently Harvard's assistant vice-president for Community Affairs, now working in commercial real estate and acting for Harvard as a consultant. (Although Ms Nixon has provided the Congress with details of her activities-as professional lobbyists are required to do-from the beginning of July 1977, she did not in fact register until February 28 this year, coincidentally handing in her registration two days before an article describing her activities as a registered lobbyist appeared in the Harvard Crimson.)

The scientific and university-based lobbyists soon met success. Mr Rogers and the Administration revised their Bill to state that the Secretary for Health, Education and Welfare could permit local, more stringent legislation only if it could be demonstrated that this was "necessary" (a word which has since taken on an important significance) to protect the health of people and the environment.

This was the form in which the Bill went before the House Commerce Committee, under the chairmanship of Representative Harley Staggers, last 
autumn, and it won from Ms Nixon the statement that she was "generally in favour"

However, during committee consideration of the Bill, an amendment was passed changing "necessary" to "reasonable". Shortly afterwards, the Harvard lobbyists withdrew their support, and $\mathrm{Mr}$ Staggers who had also been contacted by a number of scientists questioning the whole wisdom of the Federal legislation, blocked further discussion by the committee.

The universities' lobbyists then agreed with Mr Staggers to produce a new Bill which would include preemption of all Federal agencies (except the Occupational Health and Safety Administration) by the Department of Health, Education and Welfare, and Federal preemption of all state and local governments. A draft Bill containing these provisions was circulated to all members of the Friends of DNA network in the middle of November.

In a subsequent memorandum, Ms Nixon and $\mathrm{Mr}$ Moulton circulated a copy of the local ordinance covering DNA research which was being considered by the City Council of Berkeley, California-and has since also provided the model for legislation that has been proposed to the State of Massachussetts. The memorandum said the ordinance "clearly illustrates the need for Federal preemption".

A revised version of the Bill was prepared at the end of December with the aid of an Arlington lawyer, and a copy sent to Mr Staggers, who introduced it virtually unchanged into the House of Representatives on 19 January. Meanwhile, members of $\mathrm{Mr}$ Rogers' staff had produced their own revised Bill which omitted any discussion of the preemptive issue.

Following discussions, a joint Bill supported by both $\mathrm{Mr}$ Staggers and $\mathrm{Mr}$ Rogers was prepared and made public at the American Association for the Advancement of Science meeting in Washington in February. It contained the preemption provision as suggested by the universities' lobbyists.

In a memorandum from Ms Nixon and $\mathrm{Mr}$ Moulton, the Friends of DNA were told that "several of us have read the draft Bill and in its total context feel it's an acceptable Bill". However, members of the network were warned of a "major problem" that, particularly in the preemption section, "there is no padding, and therefore its acceptability may not continue if it is amended during mark-up".

The memo continues: "If you agree with our opinion of the Bill and our concern for amendments, please make your opinions know to $\mathrm{Mr}$ Staggers, $\mathrm{Mr}$ Rogers, and all members of the full

\section{committee"}

At the mark-up session on 13 March, the full committee considered the joint Staggers-Rogers Bill, now formally known as HR 11192. Two amendments seeking to rephrase the preemption language were voted down. The first, which would have reversed the Bill by placing responsibility on the Secretary of HEW to show that local, more stringent regulations were not necessary, had been supported by pressure groups such as the National League of Cities; the second, which would have changed "necessary" to "reasonable", was rejected on a voice vote which the chairman, in a hotly-disputed decision, refused to put to a count.

Deep political differences are revealed by the committee's report on its mark-up session. The majority report states that "local action is not always based upon careful consideration or understanding of the available facts on a particular issue".

In contrast, the six dissenting members who voted against the final version

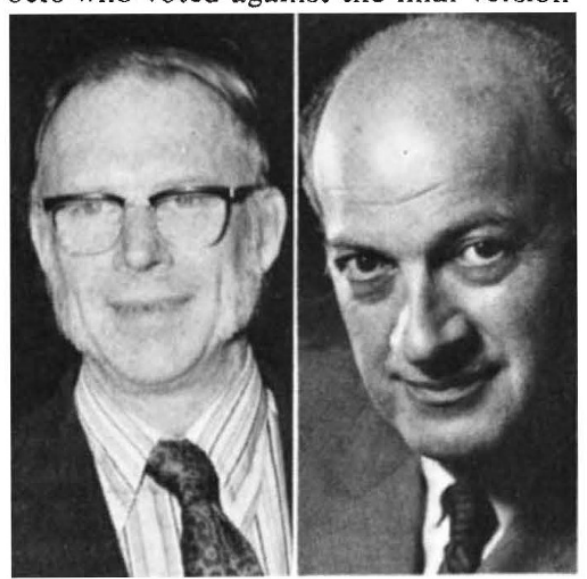

Science lobby: Halvorson (left), Handler

of the Bill state that "our fundamental concern as to the preemption issue is with the notion that a scientific elite and an insular federal bureaucracy know what is best for the people", an attitude which is "contrary to the principles of Jeffersonian democracy

In Cambridge, ex-mayor Alfred Vellucci, who was largely responsible for moves that led to the setting up of a local Biohazards Committee to oversee the regulation of DNA research at Harvard and Massachusetts Institute of Technology, called a press conference to declare that he would "put up a fight" against Federal preemption. Sheldon Krimsky of Tufts University, a member of the panel which had suggested setting up the committee, announced that "everything that occurred in Cambridge will really be meaningless if this legislation is passed".

Unless an amendment is offered when HR 11192 is debated on the floor, the Staggers-Rogers Bill seems likely to prevail in the House of Representatives, with full Federal preemption. $\mathrm{Mr}$ Moulton said last week that he was "optimistic" about the outcome.

In the Senate, however, things are much less certain. Senator Edward Kennedy, the author of a Bill which was the focus of attention last year until he dropped his support for it, has been consistently opposed to Federal legislation. And last month, rather than introduce the Staggers-Rogers Bill into the Senate as had been predicted, the Senator introduced his own Bill in which preemption is not mentioned.

The universities' lobbyists have been trying hard to get this reversed. The Bill prepared for Mr Staggers was also given to the staff of Senator Jacob Javits of New York, who had previously argued against Kennedy, in favour of strong Federal preemption.

A few weeks ago, the chances of success looked high, since the various senators (apart from Kennedy) most closely involved with the DNA issue seemed to favour fairly strong Federal preemption. But two recent events are giving the lobbyists cause for concern.

The first is a subtle but significant shift in the Administration's position on preemption, following a heated dispute between the domestic counsel of the White House, who has in general been against strong Federal preemption, and the director of the National Institutes of Health, Dr Donald Frederickson, who has in general been in favour of it.

Presenting evidence to a subcommittee of the House Science and Technology Committee last week, Dr Gilbert Omenn, assistant director of the President's Office of Science and Technology, revealed that a compromise had been reached. $\mathrm{He}$ said that while the Administration supported HR 11192 , it felt Congress's intentions could be met with a test that the change proposed by the states or localities be "reasonable" rather than "necessary".

A further factor likely to affect the Senate debate is the imminent publication of the report on hearings held by Senator Adlai Stevenson last November. These are expected to contain detailed recommendations for legislation, including suggestions for a weaker preemptive provision which could be put forward by Stevenson as a compromise between Kennedy and Javits.

Neither of these two initiatives has been welcomed by the Harvard-based lobbyists. Although the debate on the adequacy of the NIH's safety guidelines has calmed down in a way that most scientists find acceptable, the political reverberations threaten to linger on into what could again become a long, hot summer debate. 